\section{Ground-Water Recharge in the Southern High Plains of Texas and New Mexico}

- Warren W. Wood
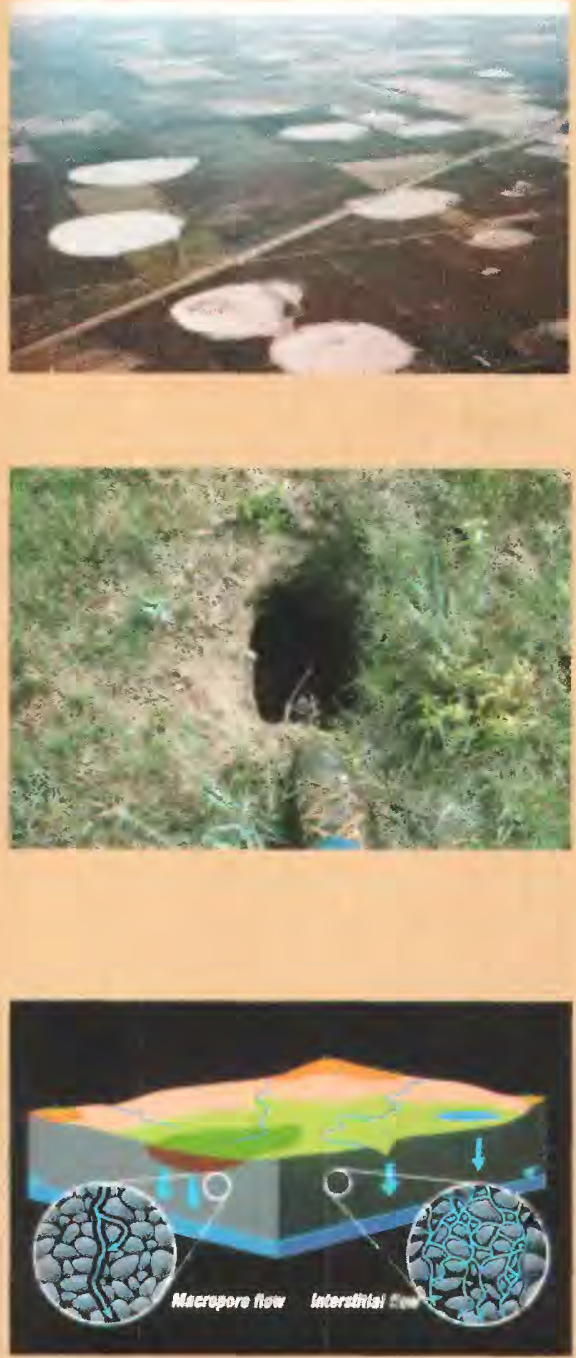

US Department of the Interior

US Geological Survey

\section{INTRODUCTION}

The Southern High Plains (fig. 1) has limited fresh surface-water resources and depends extensively on the approximately 80,000 water wells in this area to support the large demand of irrigated agriculture, feed lots, and rural water supply. To efficiently manage this ground-water resource and protect it from contamination, it is important to know, among other things: 1) the amount of water recharge to the aquifer each year; 2) where that recharge physically occurs; 3 ) when the recharge occurs; and 4) whether the recharge is through larger openings (macropores) or between the individual grains (interstices) forming the rock framework of the aquifer.

The $80,000 \mathrm{~km}^{2}(31,900$ sq. miles) of the Southern High Plains is defined by the elevated plateau south of the Canadian River, east of the Pecos River. and west of the Eastern Escarpment. On the southern edges, the Southern High Plains sediments gently overlap the Edwards Plateau. On an average, the upper 100 meters $(300 \mathrm{ft}$ ) of sediment constitute the High Plains aquifer of the region. The aquifer includes the Ogallala and Blackwater Draw Formations and sediments in the playa-lake basins. The Ogallala consists of river-lain clay, sand, and gravels, and thins to the south and southeast. It was deposited on a bedrock surface of much older sediments with relatively low permeability. This low-permeability unit forms the base of the active ground-water system. A 3- or 4-m (10 to $12 \mathrm{ft}$ ) thick calcrete "caprock" forms the upper surface of the Ogallala Formation and is largely responsible for the plateau topography. Overlying the Ogallala is the Blackwater Draw Formation, a wind-deposited sediment that reaches a maximum thickness of approximately $27 \mathrm{~m}$ (90 ft). Two to $3 \mathrm{~m} \mathrm{(6} \mathrm{to} 9 \mathrm{ft}$ ) of sediment are deposited over the Blackwater Draw Formation in more than 20,000 small, playa-lake basins. Holliday (1995) and Reeves and Reeves (1996) provide a current summary of the geology and stratigraphy of the area.

The low-relief surface of the Southern High Plains slopes to the southeast with elevation declining from greater than $1,400 \mathrm{~m}(4,600 \mathrm{ft})$ to less

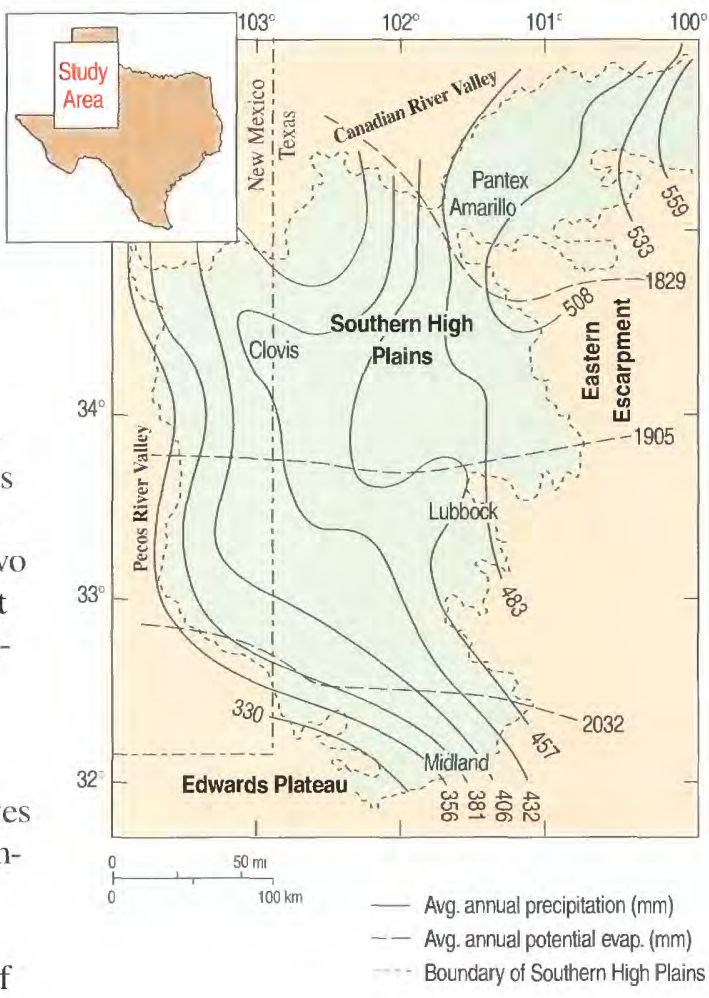

Fig. 1. Map of the Southern High Plains showing geomorphic boundaries, major cities, rainfall, and potential evaporation. 
than $915 \mathrm{~m}(3,000 \mathrm{ft})$. The surface of the ground-water table mirrors the topography of the land surface, falling in elevation from northwest to southeast with a gradient of approximately $1.9 \mathrm{~m} / \mathrm{km}$ ( $10 \mathrm{ft} / \mathrm{mile}$ ). Under natural conditions, ground water was discharged to springs along the eastern escarpment; but since the substantial increase in irrigation in the 1940's, discharge has been largely through pumping of wells, and most of the springs are either no longer active or have greatly reduced discharges. Ground-water levels in

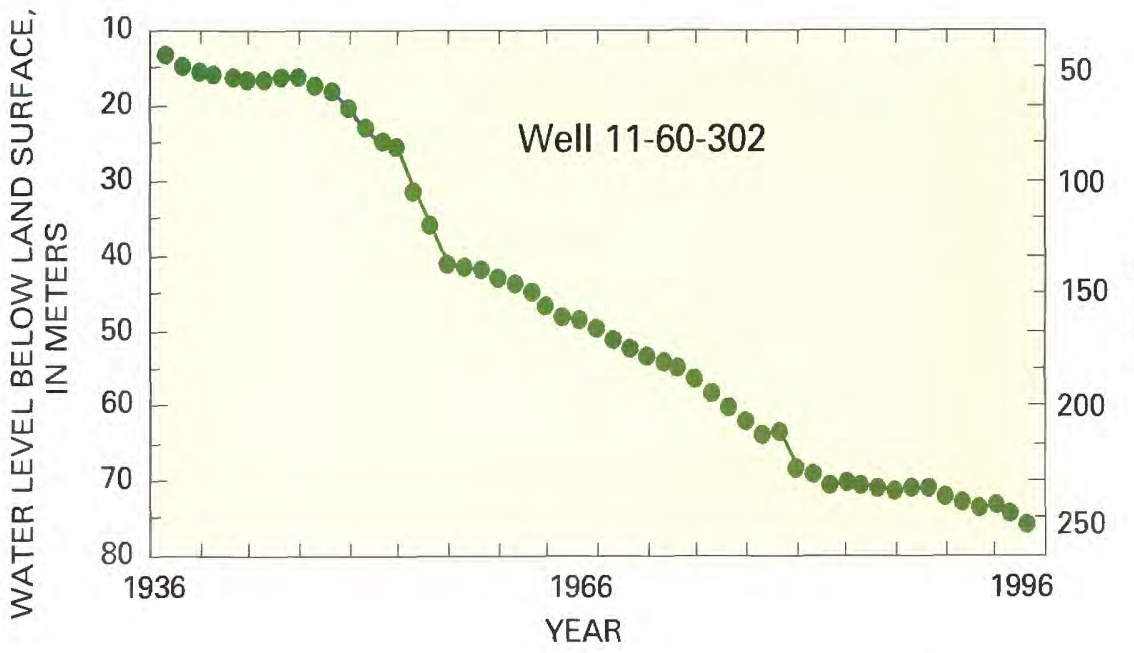

Fig. 2. Graph showing ground-water decline since 1936 from well 11-6302 northeast of Lubbock, Texas. the area are declining because pumping exceeds recharge. Figure 2 illustrates this decline in a well northeast of Lubbock, Texas.

The annual precipitation on the Southern High Plains is approximately $450 \mathrm{~mm} / \mathrm{y}$ ( $18 \mathrm{in} . / \mathrm{y})$ and increases from the southwest toward the northeast (fig. 1). Potential evaporation averages nearly $1,900 \mathrm{~mm} / \mathrm{y}(75$ in./y) - approximately four times precipitation - and increases toward the south. Surface-water outflow from the Southern High Plains is negligible because more than 98 percent of the area is internally drained to the 20,000 playas (fig. 3). Over 95 percent of all precipitation is lost by direct evaporation from the surface and transpiration of vegetation. Because most of the playa-lake basins are dry much of the year, there is no perennial storage in them.

\section{GROUND-WATER RECHARGE}

\section{How much?}

The natural topographic boundaries and slope prevent surface water from entering the Southern High Plains, while the relatively high elevation prevents upward flow from underlying aquifers. Thus, all ground water in this area originates as precipitation on the surface of the Southern High Plains. Theis (1937), using physical methods, estimated that average recharge was approximately $12 \mathrm{~mm} / \mathrm{y}$ (0.5 in./y). Wood and Sanford (1995), using the chemistry of the water, estimated that average recharge was approximately $11 \mathrm{~mm} / \mathrm{y}(0.5 \mathrm{in} . / \mathrm{y})$. These two independent techniques indicate

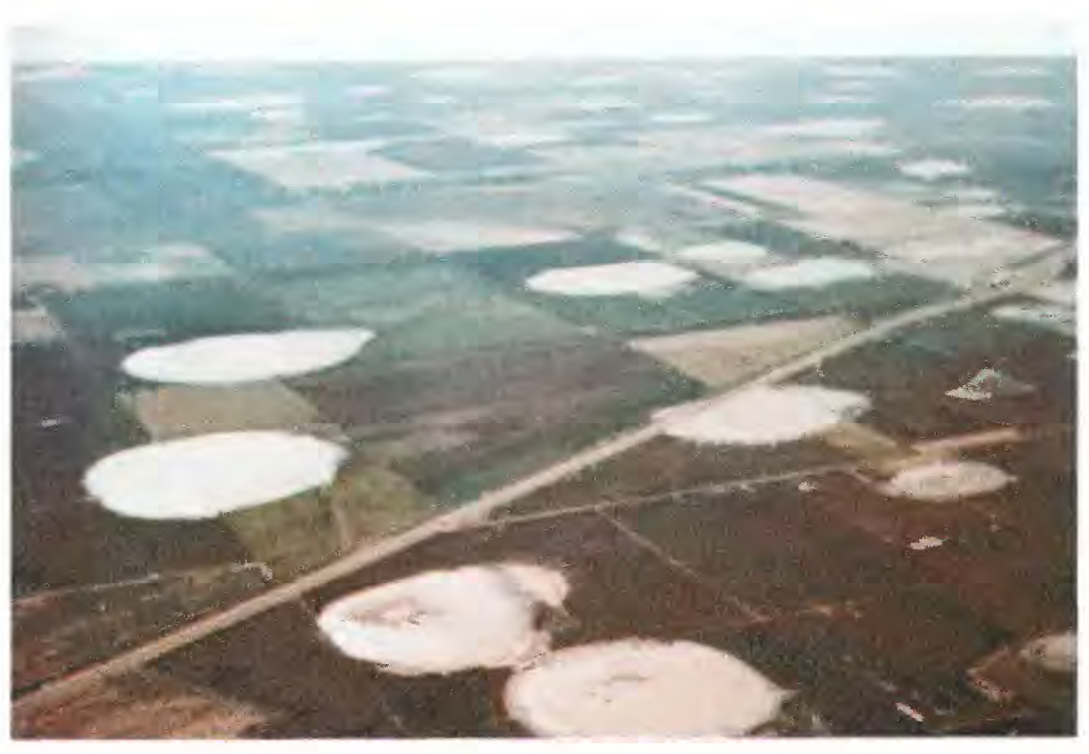

Fig. 3. Aerial photograph of playa lakes after a spring rain north of Lubbock, Texas. Diagonal highway is a four-lane interstate for scale (courtesy of the High Plains Underground Water District \#1). 


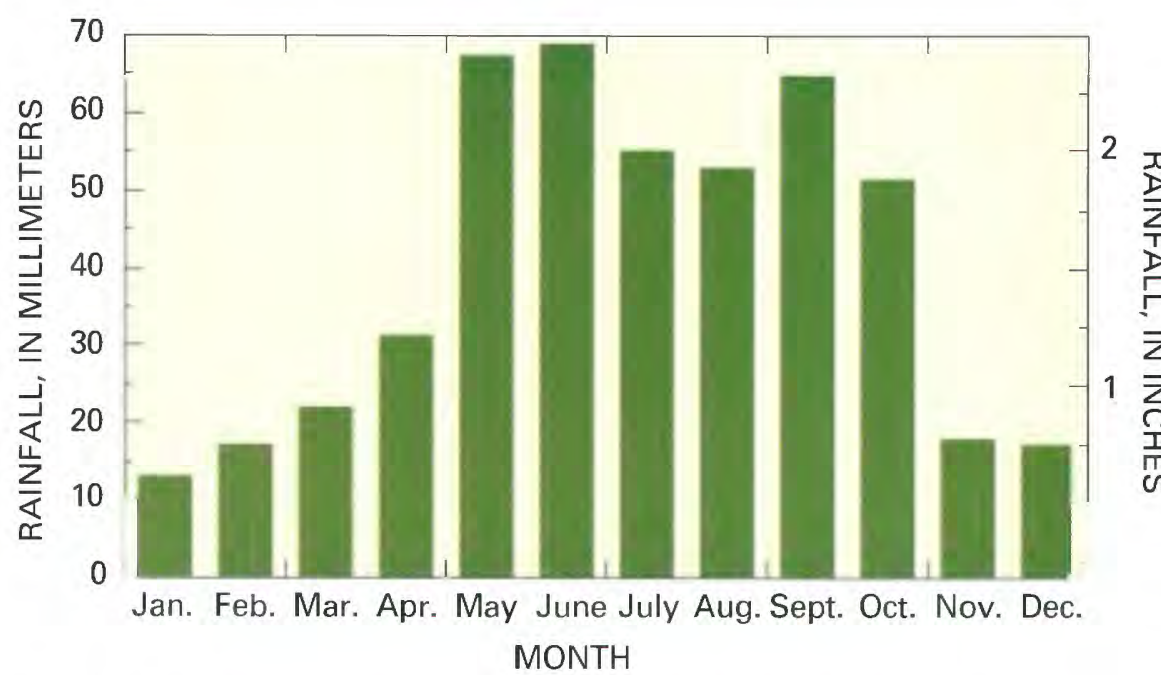

Fig. 4. Graph showing average distribution of rainfall by month at Lubbock, Texas from 1911 through 1998.

\section{When?}

Because much of the ground-water recharge in the Southern High Plains occurs through playa basins, the timing of recharge can be identified as the period when the playas are most likely to receive water from precipitation. Figure 4 shows that rainfall is greatest in the months of May through October, so most of the recharge would be expected to occur during that time interval. Given the same rainfall amount. intensity, and soil moisture conditions, more runoff might be expected in May through October, resulting in the greatest ground-water recharge during this period.

\section{What type?}

Recharge can occur two ways: by macropore flow through desiccation cracks, animal burrows, root tubes, and solution pipes (fig. 5), or by interstitial flow between individual grains of the aquifer. The important difference between macropore and interstitial recharge is that macropore flow allows solutes (substances dissolved in water) to reach the water table faster because of greater permeability and less contact with surfaces (fig. 6). Macropore flow provides less opportunity for contaminants to be absorbed or mitigated before entering the water table, and natural bacteria and virus filtering is also significantly reduced.

Sixty to 80 percent of the total recharge is through macropores, and between 15 and 35 percent is through interstitial flow in the playa floor (Wood and others, 1997). All of the analyses are based on natural conditions, however, and it is clear that most playa basins have been modified by agricultural activity. Thus, the recharge might be significantly greater if increased runoff resulted from these modifications or if the permeability of the playa floor were increased. Clearly, this is a study in progress, and continued monitoring of water-level changes with time is important. as are detailed studies of the recharge process.

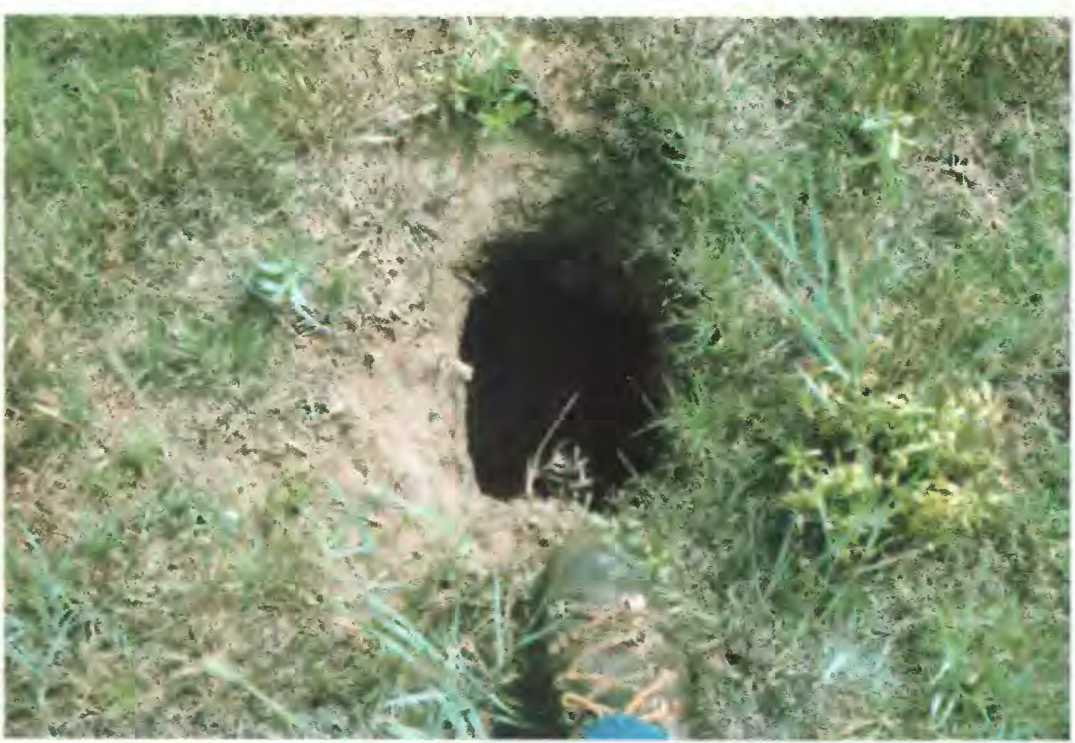

Fig. 5. Photograph of a recently developed solution pipe in a playa floor near Pantex, Texas. A man's shoe provides the scale.

\section{IMPLICATIONS FOR WATER MANAGEMENT}

By knowing the amount of recharge, a strategy for water production can be developed that makes the most efficient use of the available water and improves sustainability. By knowing that most of the recharge occurs through the playa floors and immediately surrounding area, it is also possible to develop an aquifer protection strategy that will affect only about 5 or 6 percent of the area represented by playa floors. If temporary storage of potentially injurious materials must take place in the playa basins, knowing the timing of most recharge can be helpful in limiting potential damage to the water quality. Finally. knowing that most recharge occurs through macropores rather than interstitial 


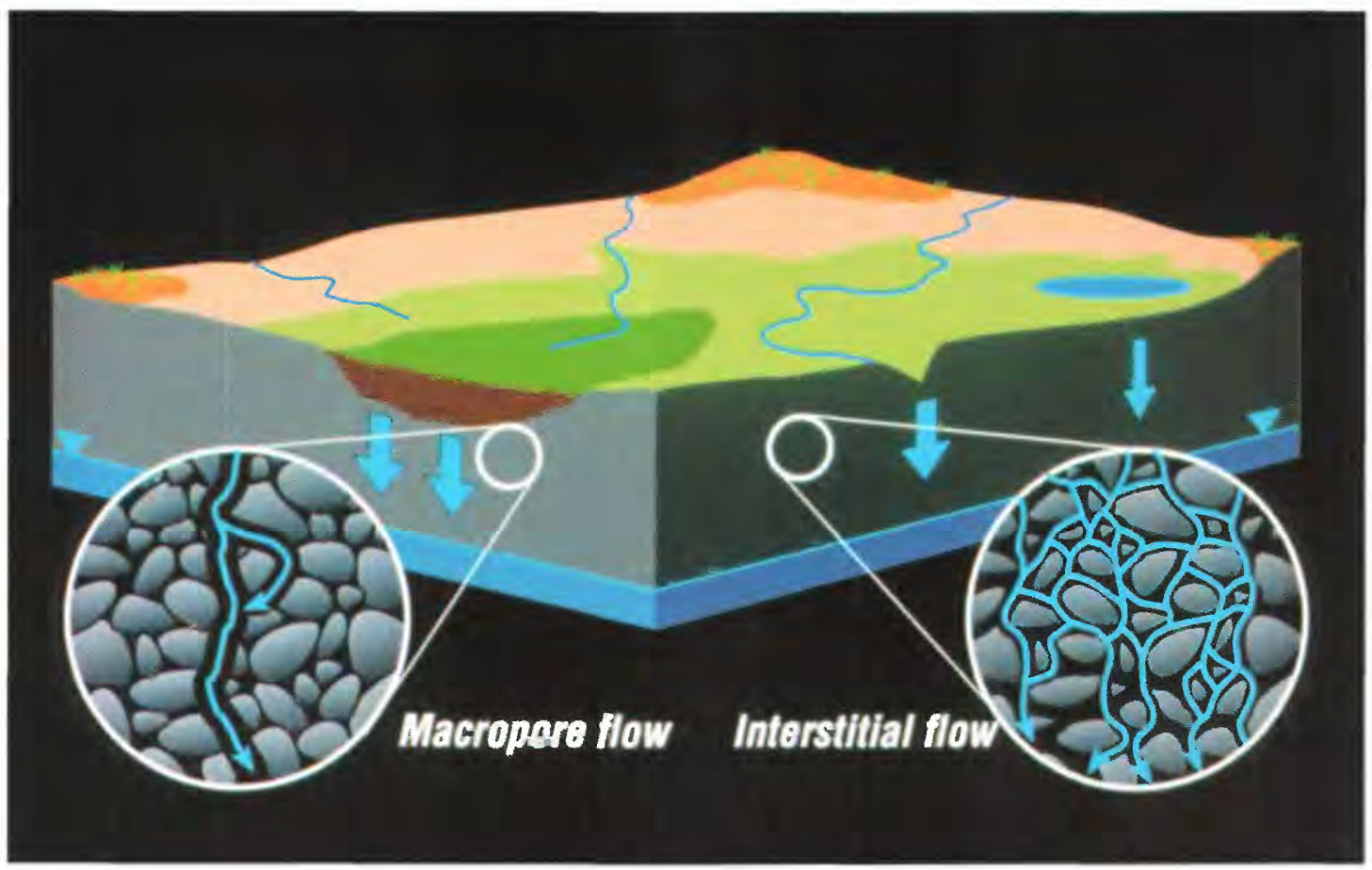

Fig. 6. Diagram illustrating the difference in the flow paths between macropore and interstitial flow in the unsaturated zone above the aquifer.

flow provides a warning that any objectionable material placed in the playa basin is likely to reach the water table rapidly with little filtering or sorption. This is particularly important if farming practices result in increased runoff to the playas.

\section{ADDITIONAL READING}

Holliday, V. T., 1995, Stratigraphy and paleoenvironments of late Quaternary valley fills on the Southern High Plains: Geological Society of America Memoir 186, 136 p.

Reeves, C. C., Jr., and Reeves J. A., 1996, The Ogallala Aquifer, v. 1: Lubbock, Texas, Estacado Books, 360 p.

Theis, C. V., 1937, Amount of ground-water recharge in the Southern High Plains: Transactions of the American Geophysical Union, v. 18, p. $564-$ 568.

Wood, W. W., and Osterkamp. W. R.. 1987. Playa-lake basins on the Southern High Plains of Texas and New Mexico, Part II-a hydrological model and mass-balance argument for their development: Bulletin, Geological Society of America, v. 99, p. 224-230.

Wood, W. W., and Sanford, W. E., 1995, Chemical and isotopic methods for quantifying ground-water recharge in a regional, semi-arid environment: Ground Water, v. 33, no. 3, p. 458-468.

Wood, W. W., Rainwater K. A., and Thompson, D. B., 1997, Quantifying macropore recharge: examples from a semi-arid area: Ground Water, v. 35 , no. 6 , p. 1,097-1,106.
For additional information, contact:

Linda S. Weiss, District Chief U. S. Geological Survey 5338 Montgomery Blvd. NE Suite 400/300

Albuquerque, NM 87109

Phone: (505) 830-7901

Fax : (505) 830-7998

e-mail_lsweiss@usgs.gov

Richard 0. Hawkinson,

District Chief

U. S. Geological Survey

8027 Exchange Drive

Austin, TX 78754-4733

Phone (512) 927-3502

Fax : (512) 927-3590

e-mail_rohawkin@usgs.gov

or call: 1-888-ASK USGS 